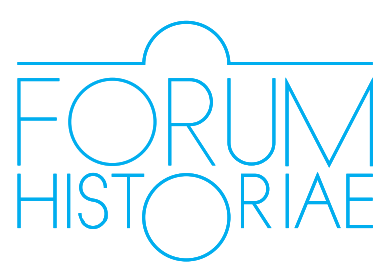

\title{
Vystúpenia z vojen: od napoleonských vojen po druhú svetovú vojnu
}

\author{
Bohumila Ferenčuhová - Antoine Marès - Michal Kšiňan
}

\begin{abstract}
:
FERENČUHOVÁ, Bohumila - MARÈS, Antoine - KŠIŇAN, Michal: Exiting Wars: from Napoleonic Wars to World War II.

This article is an introduction to the thematic issue of Forum Historiae 2/2018 dedicated to the subject of exiting wars in France and Central European countries in 19th and 20th centuries. In addition to introducing the main research questions and hypotheses, which the authors of the issue worked with, and to the outline of their main conclusions, the editors also provide a brief comparison of exiting wars in East-Central Europe in 20th century.
\end{abstract}

Keywords: exiting wars, France, East-Central Europe, World War I, World War II, Napoleonic wars

A ktuálne číslo Forum Historiae ponúka našim čitatelom články, ktoré sa venujú vystúpeniam z vojen (sorties de guerre), teda tematike, ktorá si získava stále väčší záujem vedeckej obce či už v strednej Európe, ale aj vo Francúzsku. Mimochodom, reforma bezpečnostného sektora je jednou z priorít zahraničnej politiky Slovenska, ktorej cielom je zabezpečit' jeho efektívne fungovanie a demokratickú kontrolu, ktorá „je jednou zo základných podmienok pre zdravý štát a realizáciu d’alších reforiem najmä v situáciách po ukončení konfliktu“. 1 My sa však zameriame na historické vystúpenia z vojen. Náš úvod je rozdelený na dve časti, ked’ v prvej ponúka jeho francúzsky spoluautor globálny a komparatívny pohlad na vystúpenia z vojen v regióne mediánnej Európy ${ }^{2}$, tak v druhej časti zase slovenskí zostavovatelia tohto tematického čísla v skratke charakterizujú jeho obsah.

\section{Krátke zamyslenie nad vystúpeniami z vojen v mediánnej Európe na- miesto úvodu}

Pripomenutie našich stretnutí je v tomto úvode zároveň pripomienkou jednej polstoročnice. V Inštitúte slovanských štúdií v Paríži sa najmä pod záštitou Victora-Luciena Tapiého, vel'kého historika novoveku krajín strednej Európy, uskutočnila v roku 1968 konferencia venovaná zrodu Československa. Oslavovali sme jeho pät’desiate výročie a išlo o prvé vel'ké stretnutie francúzskych, slovenských a českých historikov. Komisia, ktorá vtedy vznikla, zorganizovala už nasledujúci rok v Bratislave konferenciu zameranú na Malú dohodu. Jej organizátormi boli

10 reforme bezpečnostného sektora s expertmi z krajín V4 a Ukrajiny (2015). Dostupné na internete: https://www.mzv.sk/zahranicna-politika/slovensko-a-v4/slovenske-predsednictvo-v4/aktualnespravy/-/asset_publisher/w7vqBWMUyCYw/content/o-reforme-bezpecnostneho-sektora-s-expertmi-zkrajin-v4-a-ukrajiny (posledný náhl'ad 22.11. 2018).

2 Z francúzštiny ju preložila Silvia Ruppeldtová. 
Bernard Michel a na československej strane Anton Vantuch a L'udovít Holotík. Spolupráca sa potom na takmer dvadsat' rokov prerušila, pretože roky československej „normalizácie“, ktoré nasledovali po invázii vojsk Varšavskej zmluvy 21. augusta 1968, nevel'mi priali bilaterálnym vztahom. Bernard Michel, ktorý v rokoch 1985 až $2004^{3}$ pôsobil ako šéf Katedry stredoeurópskych dejín na Sorbone, sa v roku 1989 rozhodol tieto stretnutia obnovit': súčast'ou dobrodružstva, ktorého som sa zúčastnil aj ja, boli René Girault a Céline Gervaisová. Vel'mi dobre si spomínam na naše rozhovory v prestávkach konferencie, počas ktorých ma ohúrila sloboda slova našich slovenských priatelov: podla nich už veci nemôžu trvat' dlho a niečo sa určite stane. A skutočne, o niekol'ko mesiacov neskôr, v novembri a decembri toho roku, sa komunistický režim zrútil a vztahy medzi strednou Európou a Francúzskom sa opät' plynulo obnovili.

Naše stretnutia sa začali opakovat' každé dva roky, či už v Bratislave, Paríži alebo v Prahe. V roku 2003 ma Bernard Michel požiadal, aby som ho vystriedal. Spoločnou zásadou vtedy aj dnes ostáva stanovit’ si spoločnú tému a obmieňat' miesto konania. Ako príklad si pripomeňme posledné témy: Miesta pamäti v Prahe; Životopisné cvičenia v Bratislave; Sprostredkovatelia medzi Francúzskom a strednou Európou v Paríži; Vzdelávanie v procese vzájomného poznania v Pardubiciach; a napokon v Bratislave konferencia s názvom Ako vystúpit’ z vojny. Výsledkom každého z týchto stretnutí je kvalitná knižná publikácia.

Prečo sa tu teda zaoberat' „vystúpeniami z vojny“? Sčasti to súvisí s vývojom francúzskej historiografie v poslednom desat'ročí: jednak mám na mysli konkrétnu publikáciu, ktorú editovali Christophe Prochasson a Stéphane Audoin-Rouzeau a ktorá vyšla v roku 20084; jednak celú sériu výskumných programov, týkajúcich sa vystúpení z prvej svetovej vojny pri príležitosti jej storočnice. Práve to je jedna z výskumných tém UMR SIRICE ${ }^{5}$, ktorú založil Robert Frank a vedie ju Marie-Pierre Reyová. Problematika vystúpení z prvej svetovej vojny je v súčasnosti hlavnou témou výskumu. V nadchádzajúcich rokoch sa bude skúmat' optikou nových výkladov tohto obdobia a zo stredoeurópskej perspektívy. Garantmi sú Étienne Boisserie a Catherine Horelová. Naším súčasným cielom je prepojit' perspektívu západného výskumu s perspektívou stredoeurópskou. Konferencia má za ciel' zanalyzovat', ako v priestore, ktorý v súčasnosti zodpovedá jednotlivým krajinám Visegrádskej štvorky a Francúzsku, prebiehalo vystupovanie z vojenských konfliktov, a to od obdobia napoleonských vojen až po vystúpenia z druhej svetovej vojny. Dôležité je sledovat' vplyv týchto „prechodov" na jednotlivca, ako aj na celú spoločnost'. Je pri tom nevyhnutné pribrat’ do úvahy zmeny sociálnych a intelektuálnych paradigiem, ktoré v dôsledku vojen nastali.

3 Zomrel v roku 2013.

4 AUDOIN-ROUZEAU, Stéphane - PROCHASSON, Christophe (ed.) Sortir de la Grande Guerre. Le monde et l'après-1918. Paris : Tallandier, 2008.

5 Unité mixte de recherche, Sorbonne, Identités, relations internationales et civilisations de l'Europe Organizácia zjednocujúca výskumných pracovníkov a učitelov na univerzitách Paris 1 Panthéon-Sorbonne, Paris-Sorbonne a CNRS. 
Tento krátky úvod si kladie za ciel' komparatívnou optikou uvažovat' o vystúpení z vojenských konfliktov 20. storočia v širokej perspektíve, ktorá zahŕňa mediánnu Európu a týka sa troch konfliktov: prvej svetovej vojny, druhej svetovej vojny a v nadväznosti na ňu vojny studenej. Na tomto mieste je vhodné upresnit', že pod pojmom mediánna Európa sa rozumie oblast', ktorá sa rozprestiera od západu na východ medzi Nemeckom a Ruskom; a od severu na juh v priestore medzi Baltským morom, Čiernym morom a Jadranským morom. Ide teda o rozšírenú verziu územia, ktoré sa $\mathrm{v}$ anglo-severoamerickom svete označuje pojmom stredovýchodná Európa (East-Central Europe). Z nášho hl'adiska toto územie zahŕňa tri hlavné podcelky: pobaltskú Európu, strednú Európu a Balkán, resp. juhovýchodnú Európu. Ale poňatie hraníc medzi nimi je ovel’a menej dôležité ako predstava o pohybe l'udí, ktorý prebiehal jednak vnútri takto definovaného európskeho priestoru, jednak vo vzt’ahu s nemeckými, ruskými, švédskymi či osmanskými susedmi. ${ }^{6}$

Región charakterizujú isté špecifické črty, ktoré musíme vidiet' v priamom vzt’ahu s vystúpeniami z vojenských konfliktov: neprítomnost' koloniálnej expanzie a svojho premietnutia sa do svetov mimo európskeho kontinentu (ak nehovoríme o migračných vlnách, ktoré sa začali v 17. storočí, alebo o viac či menej významnom, doposial' trvajúcom fenoméne exilu); neprítomnost' silnej námorníckej kultúry v národných kultúrach širokého regiónu (s výnimkou časti Chorvátov); neexistencia geopolitickej stability, jav sprevádzaný opakovanou štátnou diskontinuitou a častým presúvaním hraníc. Prevládajúcou črtou tejto časti Európy až do obdobia druhej svetovej vojny je navyše výrazná etnická, náboženská a jazyková heterogenita: vyplýva z toho nevyhnutnost' súžitia, ktoré sa bud' pretavuje do kompromisu a mnohojazyčnosti, alebo naopak do vzájomnej konfrontácie, občianskej vojny či vylúčenia. Dá sa tvrdit', že práve táto rôznorodost' bola prekážkou zakladania národných štátov, a to až do konca druhej svetovej vojny. To bol moment, v ktorom sa táto mnohorakost' často tragicky zredukovala a napokon prakticky celkom vymizla (s výnimkou priestoru bývalej Juhoslávie a Pobaltia). Dôsledkom tejto vkorenenej nestability býva pocit krehkosti a neistoty, ktorý sa o to väčšmi znásobuje, o čo viac ho trvalo a opakovane využívali a využívajú politickí predstavitelia, niekedy dokonca intelektuáli. A to až do takej miery, že sa tento pocit stal integrálnou súčastou spôsobu prezentácie seba samých a sebaumiestňovania: v tomto ohl'ade nesmieme podceňovat' strach z budúcnosti prejavovaný v emóciách, ktoré hýbu verejnou mienkou, v čoho dôsledku ju rovnako ovládajú ako vytvárajú. Odhliadnuc teraz od malých štátov bez tradície vlastnej štátnosti, komplex izolácie je v prípade niektorých krajín, obzvlášt' v Pol'sku a Mad'arsku7 (pozri napr. doslovné znenie mad’arskej národnej hymny) v tejto súvislosti neprehliadnutel'ný.

Všetky tieto charakteristiky, samozrejme, vyplývajú z podoby vystúpení z vojen v stredovýchodnej Európe. Jej špecifickou charakteristikou je dočasnost'. Tento

60 stredovosti tohto priestoru pozri Monde(s), č. 14, jeseň 2018.

7 Pozri napr. MARÈS, Antoine (ed.) Hymnes nationaux en Europe centrale, orientale et du Sud-Est. Paris : Cahier du Cececese-Inalco, 1993. 
región však v 20. storočí prežil ešte d’alšiu vojnu, ktorá sa zavŕšila až na prelome 80. rokov. To k dlhému radu zlomov prispieva ešte väčšmi. Pokial' ide o konflikt studenej vojny a jej základné charakteristiky, ktoré vplývali na chod jednotlivých spoločností, môžeme jej chronológiu skúmat’ v širšom rámci (1917 - 1991) alebo v užšom rámci (1947 - 1953). Zdôraznime len to, že uzatvorenost', vláda propagandy či čast' hospodárstva zameraného na obranu, ktorými sa komunistický režim vyznačoval, sa zhodujú s charakteristikami spoločnosti vo vojne. V závere uvidíme, či má zmysel porovnávat’ prelom 80. a 90. rokov 20. storočia so zlomom, ktorý už predtým nastal s nástupom 20. rokov a rokom 1945.

Chronologická asymetria, ktorá je jednou z hlavných charakteristík odlišujúcich vývoj v porovnaní so západnou Európou, je príznačná aj pre povojnové obdobie. Na západných frontoch prvú svetovú vojnu jasne vymedzujú roky 1914 až 1918 (v Taliansku dokonca spresnene 1915 až 1918, v Spojených štátoch amerických 1917 až 1918). Naopak, vo vel'kej časti stredovýchodnej Európy - na severe na pomedzí Pol'ska a pobaltských štátov, na juhu v oblasti Balkánu - vojna trvala ovel'a dlhšie: na severovýchode Európy sa konflikt zavŕšil až v rokoch 1919 1920. Na európskom juhovýchode sa začal už v roku 1912 prvými balkánskymi vojnami. To isté platí pre druhú svetovú vojnu: Rakúsko a Československo boli okupované už v čase medzi marcom 1938 a marcom 1939. Podrobenie teda celkovo trvalo šest' až sedem rokov. Väzba na Sovietsky zväz sa v prípade Pol'ska a pobaltských krajín začala v rozmedzí rokov 1945 až 1948 a skončila sa v období rokov 1989 až 1991. Ak teda chceme analyzovat' podoby povojnového obdobia v celom širokom regióne, tieto rozdielne chronológie musíme nevyhnutne brat' do úvahy. Vojenské konflikty sa tu totiž po oficiálnom ukončení završovali v situáciách ovel'a väčšieho zmätku a obnovovanie spoločnosti prebiehalo v podstatne t’aživejších l'udských, sociálnych a hospodárskych podmienkach.

Druhý zretel'ný rozdiel sa týka intenzity a frekvencie spoločenských ruptúr. Všetky vojny v stredovýchodnej Európe vyústili do režimov novej formy suverenity. Povojnové obdobie prvej svetovej vojny znamenalo rozpad monarchií a zrod siedmich nových štátov, z ktorých dva pôvodne vznikli už v prvom desat'ročí 20. storočia (Fínsko a Albánsko), a to nespomínam štáty, ktoré vznikli už v 19. storočí na troskách Osmanskej ríše, ako je Bulharsko; alebo tie, ktorým na svet pomohlo vít’azstvo Trojdohody (Francúzsko, Rusko, Vel’ká Británia), ako bolo Rumunsko a Královstvo Srbov, Chorvátov a Slovincov. Takýto búrlivý presun štátnych hraníc nemá v moderných dejinách Európy obdobu od čias napoleonských vojen. Predefinovanie nových národných území, ktoré sa bud' zväčšili, alebo naopak zmenšili (Rakúsko, Mad'arsko, Bulharsko), bol nesmierne zložitý proces.

Na zlomy nebolo menej bohaté ani povojnové obdobie po druhej svetovej vojne. Ak aj presun hraníc neprebiehal natol'ko dramaticky (okrem hraníc Pol'ska, ktoré sa presunuli sto kilometrov smerom na západ a dvesto kilometrov na východ) a zmeny zasiahli predovšetkým západné hranice ZSSR na úkor susedných krajín (Fínsko, pobaltské krajiny, Pol’sko, Československo a Rumunsko), hlboko 
bola zasiahnutá nezávislost’ režimov: tri pobaltské štáty sa dostali pod vplyv ZSSR, čím sa potvrdili podmienky stanovené už v rokoch 1939 až 1940. Sovietizáciu všetkých týchto krajín umožnila ich priama okupácia sovietskou armádou s výnimkou Albánska, Juhoslávie a Československa alebo geografická blízkost' sovietskej armády. Nemilosrdné prevzatie moci komunistickými stranami, ktoré podporovali okupanti, prebiehalo od jari 1945 do februára 1948, a to v rôznom rytme: Juhoslávia, ktorá okupovaná nebola, prijala komunistický režim paradoxne ešte pred Rumunskom, Pol'skom, Mad'arskom a Československom. Oslobodenie týchto krajín sa vel'mi rýchlo zvrtlo na novú stratu suverenity: stalinistické obdobie rokov 1948 až 1953 suverenitu zredukovalo na nulu. Celý región zjednocoval status l'udovodemokratického zriadenia, v ktorom však v praxi vládla jediná strana. Autonómia v zahraničnej politike celkom zanikla počnúc letom 1947, ked’ na nátlak Sovietskeho zväzu Praha a Varšava odmietli Marshallov plán.

Nešlo teda len o ruptúru v štátnych útvaroch, ale aj o zlom politický a inštitucionálny. Sme svedkami istej stabilizácie na západný spôsob, imperiálne režimy rokom 1918 uvol'nili miesto parlamentným monarchiám alebo republikám. Ale s nimi staré praktiky vonkoncom nevymizli. Stále bola prítomná hrozba, že sa „reinkarnujú“ do kultu osobností. Vzniká úsilie naočkovat’ parlamentnú demokraciu na územiach, ktoré možno nie sú celkom pripravené prijat' ju - či už preto, že sociálne štruktúry vzhl'adom na svoju archaickost' spôsobovali, že l'udia ešte nenadobudli dostatočnú politickú kultúru; alebo preto, že istá skupina l'udí demokraciu rovno odmietala, pretože podla nej protirečila národným záujmom a zvrchovaným princípom bezpečnosti: to je najmä prípad Józefa Piłsudského v Pol’sku. Väčšina nových krajín však predsa prijala ústavy, ktoré väčšmi ako z domácich tradícií chudobných na demokratickú skúsenost' čerpajú zo západných modelov. Na výzvu v podobe etnickej a národnostnej rôznorodosti sa všade - okrem vel'mi homogénneho Rakúska - odpovedalo silným centralizmom. Ten ale sám osebe začínal vyvolávat' d’alšie frustrácie a odpor. Vyústil do nestability, ktorú podporili susedia a ktorá vyvolala viac alebo menej rýchly zánik demokratických inštitúcií v prospech autoritárskych mocností, a to od roku 1919 v Mad’arsku a od roku 1929 v Juhoslávii. V tomto procese tvorilo výnimku jedine Československo.

V roku 1945 sa geopolitická situácia mení: po zlyhaní parlamentarizmu medzivojnového obdobia importovaného zo Západu, po hospodárskej kríze, ktorá poznamenala celý región, po hrôzach vojny, neschopnosti elít zvrátit’ túto katastrofu a v dôsledku celkovej vyčerpanosti sa čast’ populácie v tej-ktorej krajine - často sa hovorí o 10 \% v Mad'arsku, 40 \% v českých krajinách - rozhodne prijat' tretiu cestu v podobe spolužitia s komunistami. Tento proces „konverzie“ z intelektuálnej stránky dobre rozanalyzoval Czesław Miłosz. Predchádzajúce režimy v mnohom diskreditoval obraz katastrofickej kolaborácie; demokratov, ktorí ju odmietli, okupanti prevalcovali a po roku 1945 im už neostávalo viac síl bojovat' proti komunistickým stranám, ktoré navyše podporoval Sovietsky zväz. Práve za takýchto okolností vznikali l'udové demokracie, ktorých pluralizmus bol len 
naoko. Stále ostáva napísat' dejiny tohto súhlasu z pohladu zdola, resp. z pohl'adu prispôsobenia sa miestnej populácie v hlboko traumatizovanej Európe, ktorá sa ocitla v troskách.

Zlomy boli rovnako hlboké vo sfére hospodárstva a v sociálnej oblasti. V prípade prvej aj druhej svetovej vojny musíme zdôraznit' aj rozsah materiálnych strát a strát na l'udských životoch. Počas prvej svetovej vojny neboli menšie ako straty Francúzska. V prípade druhej svetovej vojny boli neporovnatel'ne vyššie: ako presvedčivý príklad nech slúži pokles počtu obyvatelov Pol’ska z 35 miliónov na 29 miliónov. V príbehoch európskeho martýrstva dosahujú obyvatelia Pol'ska, či už pol’skej alebo židovskej národnosti, smutné prvenstvo.

Teritoriálne preskupenia po roku 1918 zanechali jazvy, ktoré nezmizli ani po dvadsiatich rokoch: Pol'sku sa nepodarilo prebudovat' a pre nedostatok zahraničného kapitálu ostalo ekonomickým trpaslíkom, hoci vzhl'adom na svoju geografickú rozlohu a demografiu bolo regionálnou vel'mocou. Československo, malý „priemyselný tiger“, nedokázalo vyrovnat’ regionálnu nerovnováhu medzi západom a východom krajiny. Zásadný zlom, ktorý v smere pohybu l’udí a obchodníkov nastal po rozpade impéria, sa nepodarilo dostatočne kompenzovat' a svetová hospodárska kríza nadlho rozbíja činorodý elán druhej polovice 20. rokov. Navyše solidarita medzi regiónmi ostávala vel'mi slabá. Zmeny režimov otriasli spoločenskými elitami, a to dočasne (Mad'arsko) alebo trvalo (Československo). Hned' v prvých dňoch po prvej svetovej vojne nastúpila nacionalizácia verejných funkcií a mocenských politických elít. Zavedené pol'nohospodárske reformy pod rúškom sociálneho zámeru sledovali uprednostňovanie národného, odteraz väčšinového a často nemajetného prvku.

Radikálnost' opatrení prijatých v roku 1945 len znásobila proces, ktorý sa začal už o dve a pol desat'ročia skôr. Znárodňovanie a zoštátňovanie sa v strednej Európe dialo v zmysle etnicko-národnej „očisty“, ktorá vyhovovala dominujúcemu národu. Opatrenia boli sprevádzané masovým presunom obyvatel'stva, a to bud' formou výmeny (Poliaci - Ukrajinci, Mad’ari - Slováci), alebo formou vyhnanstva (okolo 13 miliónov Nemcov muselo región opustit'). Vstúpili sme do nových medzinárodných paradigiem: po zlyhaní mierových dohôd a dohôd o ochrane menšín, ktoré boli v rokoch 1918 až 1920 uzatvorené s úmyslom rekonštrukcie Európy a úpravy hraníc, sa územia pretvárali výmenou obyvatel'stva. To vyplynulo z už zakoreneného presvedčenia (národnostné spolužitie nie je možné) a absolútnej národnej radikalizácie (homogenizácia obyvatel'stva).

Zmena hospodárskeho a sociálneho modelu, ktorý sa odvtedy opieral viac o štát a spoločenstvo, bezpochyby súvisela s importovaním a zavádzaním sovietskeho systému. Zároveň však bola aj dôsledkom sklamania z predchádzajúcich skúseností v rokoch 1930 až 1940, ako aj narastajúceho odstupu voči liberálnemu modelu, importovanému už predtým zo Západu. Ten počas svetovej hospodárskej krízy, po ktorej nasledovala strata suverenity, na plnej čiare stroskotal. 
Aj vo vystúpeniach zo studenej vojny nájdeme mnohé podobnosti s vystúpeniami z predchádzajúcich vojenských konfliktov. A to napriek tomu, že studená vojna nebola rovnako vražedná ako predchádzajúce vojenské konflikty; preniesla sa však do gulagov a mnohí l'udia z Východu sa pokúšali utiect' na Západ: z NDR počas celého obdobia, z Mad’arska v roku 1956, z Československa v rokoch 1948 a 1968, v Sovietskom zväze vyvolala útek Arménov a Židov...

Na prelome 80. a 90. rokov sa v celom rozmanitom regióne za niekol'ko rokov zásadne menil režim, rozvrátili sa elity a nastal návrat k pluralitným konštitučným režimom. Ich zavádzanie do praxe ale bolo vzhladom na chýbajúcu skúsenost' demokracie a na obrat vo vlastníctve výrobných prostriedkov v dôsledku odštátňovania hospodárstva vel'mi zložité... Opätovné nadobúdanie suverenity kráčalo ruka v ruke s vyhl'adávaním bezpečnostných záruk zameraných prevažne proti Rusku. Ich súčast’ou bol vstup do NATO a následne do Európskej únie. Formovanie novej suverenity sprevádzal aj príliv nacionalizmov, ktoré existovali už počas komunistického režimu, ostávali však pod povrchom.

V krátkom 20. storočí, tak ako ho definuje Eric Hobsbawm ${ }^{8}$, sa vystúpenia z vojen v stredovýchodnej Európe prejavili vzostupom nacionalizmov (ktoré nadobúdali vel'mi rôznorodé podoby) a hlbokými generačnými ruptúrami v prostredí spoločenských elít, čo v západnej Európe nemalo obdobu. Boli zároveň katalyzátormi radikálnych zmien, ktoré sa dali označit’ ako revolúcie vzhl'adom na pády režimov a vzhl'adom na to, ako oficiálny diskurz tieto zlomy zdôrazňoval. Nakol'ko však tieto procesy neboli jednoznačné, historik môže okrem zlomov sledovat' i isté kontinuity, ktoré, pokial' prekročíme hranicu zdania, neboli menej očividné: prevažovali obzvlášt' na úrovni vystupovania navonok a emócií. Dajú sa však pozorovat' aj na individuálnom a kolektívnom správaní, ba dokonca i v pretrvávaní istých elít najmä v podnikatel’skej a technickej sfére. Porovnávací prístup otvára v nadchádzajúcich rokoch celkom iste nové plodné cesty. Bolo by dobré zamysliet' sa aj nad spomienkami a skúsenostami odporujúcimi tým, ktoré výsledky vojen priniesli rôznym národnostným a sociálnym skupinám. Vystúpenia z vojenských konfliktov sú vo svojej podstate mimoriadne obdobia, v ktorých sa rýchlo kryštalizujú trvalé postoje k nedávnej minulosti. ${ }^{9}$

\section{Vystúpenia z vojny vo Francúzsku a v strednej Európe}

Stretnutia francúzskych, českých a slovenských historikov sa vždy usilovali obohatit' historiografiu zúčastnených krajín informáciami o najnovších výsledkoch výskumu a nových teoretických prístupoch v historickej vede. V októbri 2015 v Pardubiciach sme stanovili tému d’alšej spoločnej konferencie ako „Sorties de guerre“. Nebolo lahké nájst’ adekvátny preklad tohto termínu do slovenčiny.

8 HOBSBAWM, Eric. The Age of Extremes: The Short Twentieth Century, 1914 - 1991. London : Michael Joseph, 1994. Vyšlo v češtine pod názvom Věk extrémů - Krátké dějiny 20. století 1914 - 1991 v roku 2010 vo vydavatel'stve Argo.

9 Dve najnovšie francúzske zhrnutia týkajúce sa 20. storočia v uvádzanom regióne: KRAKOVSKÝ, Roman. L'Europe centrale et orientale de 1918 à la chute du mur de Berlin. Paris : Armand Colin, Collection U, 2017; MARÈS, Antoine - SOUBIGOU, Alain. L'Europe centrale et médiane dans l'Europe du XXe siècle. Paris : Ellipses, 2017. 
Chronologicky sa týkal období bezprostredne nasledujúcich po vojnách, ale vo francúzskej historiografii získal hlbší zmysel. Vystúpenie z vojny je napríklad súčast’ou vojenskej terminológie. Znamená útok zo zákopu, vymanenie sa zo stavu obliehania, pokus o prelomenie frontu a získanie vítazstva či aspoň výhodného postavenia pred uzavretím prímeria či mierových zmlúv. Paul Gradvohl v štúdii venovanej vzt'ahom medzi Francúzskom a Mad’arskom v roku 1918 používa tento termín v zmysle vyústenia vojny do niečoho celkom nečakaného, s čím si vojaci ani politici nevedia dat' rady. ${ }^{10}$

Stéphane Audoin-Rouzeau chápe vystúpenie z vojny v zmysle paradigmatickej zmeny oproti staršiemu výskumu obdobia bezprostredne po vojne. Zahŕňa doň nielen zastavenie vojnových operácií, podpísanie mierových zmlúv, ale aj to, že vojna nepokračuje d’alej mierovými prostriedkami, že medzi bývalými nepriatel'mi došlo k zmiereniu, že vojna je definitívne za nami, zabudnutá. Obrazne povedané, že sa už môžeme pri Slavkove vystrojit' do starých historických vojenských uniforiem, rozostavit' vojakov a rekonštruovat' dávnu krvavú bitku bez toho, aby mala silný emocionálny rozmer. Po určitom váhaní sme usúdili, že v slovenčine budeme používat' termín vystúpenie z vojny, pričom nevylučujeme jednotlivé výstupy z vojen či dlhodobejšie vystupovania z vojen. Aktuálne číslo Forum Historiae sme chronologicky rozdelili na tri časti - vystúpenia z napoleonských vojen, z prvej svetovej a nakoniec z druhej svetovej vojny.

Francúzska historička Marie-Pierre Reyová sa v troch častiach svojho článku zamýšla nad vystúpením z napoleonských vojen, ktoré svojím geografickým rozmerom, dížkou, novou vojenskou technikou a ideologickým nábojom priniesli nielen francúzskej spoločnosti významné štrukturálne zmeny. V prvej časti sa dozvedáme o diplomaticko-vojenskej úrovni vystúpenia z vojen v rokoch 1814 1818, ked' sa Francúzsko vrátilo z pozície vyvrhela do spoločenstva európskych štátov. Politické vystúpenie z napoleonských vojen bolo omnoho komplikovanejšie a podl'a autorky sa nezavŕšilo ani v roku 1830. Asi najkomplikovanejšie prebehol tento proces medzi vojnovými veteránmi, ked’že Napoleon využil povinné odvody, čo zasiahlo dovtedy nevídaný počet bežných mužov - neprofesionálnych vojakov. Okrem obrovských strát veteráni trpeli rôznymi traumami, utrpeniami či zraneniami, na ktoré však chcela spoločnost' čím skôr zabudnút'.

Článok Dušana Kováča sa venuje procesu vystúpenia z vojny proti Napoleonovi zo strany Rakúska, ktoré do roku 1813 prehralo viacero významných bitiek s francúzskym cisárom, z čoho plynulo viacero politických ponížení. Napriek tomu sa však Rakúsku podarilo vystúpit' z napoleonských vojen ako vel'kému vít’azovi a navyše sa vo Viedni odohral kongres, ktorý z politického hl'adiska zavŕšil napoleonské vojny, za čo sa najväčšie zásluhy pripisujú rakúskemu kancelárovi Klemensovi Metternichovi. Na jednej strane Kováč uznáva Matternichove diplomatické majstrovstvo, ale na druhej strane prízvukuje, že svoju úlohu

10 GRADVOHL, Paul. La Hongrie comme révélateur de l’aporie de la stratégie française en Europe centrale après 1918. In Revue historique des armées, č. 270, 2013, dostupné na internete: http://rha.revues. org/7642 (posledný náhl'ad 6. 5. 2017). 
zohrali aj náhody a relativizuje tak jeho úspechy. Rakúsko však podla autora podlahlo ilúzii svojej vel'kosti a nevidelo svoju pozíciu na medzinárodnej scéne 19. storočia realisticky.

Príspevok Mileny Lenderovej sa venuje obdobiu, ked' bol Karel I. Schwarzenberg rakúskym vel'vyslancom v Paríži, resp. jeho parížskej misii pred Napoleonovým t’ažením do Ruska. Autorka sa opiera predovšetkým o doposial' nespracovanú osobnú korešpondenciu medzi ním a Klemensom Metternichom, ale aj o iné pramene z rovnakého obdobia. Článok sa venuje skôr spoločenskému životu v Paríži, svetu diplomatických rokovaní, súkromným záležitostiam oboch aktérov, ako aj ich osobným charakteristikám.

Stéphane Audoin-Rouzeau si vo svojom teoreticky zameranom texte na úvod kladie provokatívnu otázku - či už Francúzsko definitívne vystúpilo z prvej svetovej vojny. Obhajuje metodologický prístup vystúpenie z vojny, ktorý môže lepšie uchopit' zložitost' vyrovnávania sa s vojnovými skúsenost’ami než zaužívaný pojem povojnové obdobie. Venuje sa rozdielnej časovosti, ale hlavne pokračujúcemu smútku zo straty blízkych, ktorý sa prenáša naprieč generáciami, čím Vel'ká vojna nestráca zo svojej aktuálnosti ani dnes. Opätovné obnovenie záujmu o pamät' vel'kej vojny v 90. rokoch dáva do súvislosti s koncom studenej vojny, ktorú považuje za posledný prejav prvej svetovej vojny. Ďalšie oživenie záujmu o pamät' Vel'kej vojny možno badat' najmä v súvislosti s jej storočnicou.

Bohumila Ferenčuhová aplikuje koncept vystúpenie z vojny na problematiku konca Vel'kej vojny v habsburskej monarchii, stredovýchodnej Európe a na Slovensku, ktoré bolo súčast’ou tohto priestoru. Zvláštnu pozornost' venuje otázkam menšín a hl'adaniu možností ich medzinárodnoprávnej ochrany v zmluvách podpísaných po prvej svetovej vojne. Slovenské vystupovanie z vojny sa nedá pochopit’ z úzko lokálnej úrovne. Viaže sa na rozhodovanie o vystúpení z vojny na úrovni panovníka a ministerskej rady, ktorého sa stručne dotkla prvá čast' štúdie. Druhá poukázala na dosah týchto rozhodnutí na Slovensko. Na základe publikovaných dokumentov upozornila na situáciu pred podpisom prímeria na talianskom aj západnom fronte na slovenskom vidieku a na brutalizáciu spoločnosti vyplývajúcu z vojnových útrap. Upozornila na nebezpečenstvo jej jednostranného stotožňovania s antisemitizmom. Problematika začlenenia Bratislavy do Československej republiky poukazuje na význam tak sociálnej problematiky, ako aj vojenských a diplomatických riešení reflektovaných na lokálnej úrovni jej obyvatel'mi. Národnostne zmierlivá politika župana Samuela Zocha bola nádejou do budúcnosti. V tretej časti podrobne analyzovala na základe dokumentov Ministerstva zahraničných vecí Francúzskej republiky a Spoločnosti národov v Ženeve reakciu reprezentantov vel'mocí na mierovej konferencii na povojnovú situáciu východostrednej Európy a na riešenie problematiky menšín. Záver je odpoved’ou na niektoré francúzske práce týkajúce sa vystupovaní z Vel'kej vojny a na ich pohl'ad na zmluvy po Vel'kej vojne. Zároveň sumarizuje poznatky autorky z práce na tejto štúdii. 
Robert Frank sa vo svojej štúdii venuje vystúpeniam z druhej svetovej vojny z viacerých uhlov pohl'adu. Najprv rozoberá dedičstvo vystúpenia z prvej svetovej vojny, teda snahy, ktoré po roku 1918 neuspeli, ale stali sa inšpiráciou na obdobie po roku 1945 ako medzinárodný vplyv Spojených štátov, medzinárodná justícia, vznik OSN, sociálna otázka či európska integrácia. V druhej časti sa sústred'uje na špecifiká vystúpenia z druhej svetovej vojny ako okupácia, brutalizácia, váha spomienok či jej svetový rozmer. V poslednej tretej časti svojho príspevku zasadzuje vystúpenie z druhej svetovej vojny do kontextu celého trvania studenej vojny. Oba konflikty, ktoré predchádzali druhú svetovú vojny, ale aj po nej nasledovali, sa tak významne podpísali na zložité vystúpenia z nej.

Katarína Hradská sa venovala dedičstvu antisemitizmu na Slovensku, ktorý bol počas druhej svetovej vojny súčastou protižidovskej politiky l'udáckeho režimu a mal za následok vyvraždenie prevažnej väčšiny slovenskej židovskej komunity v koncentračných táboroch. Venuje sa nástupu antisemitizmu, jeho vyvrcholeniu vo forme deportácií, ale aj jeho povojnovému pokračovaniu. Po druhej svetovej vojne sa l'udia, ktorí prežili holokaust, rozdelili do dvoch skupín: prvá v snahe ušetrit' svojich najbližších od hrôz koncentračných táborov sa rozhodla mlčat'; druhá cítila potrebu o týchto udalostiach hovorit'. Aj tretia generácia je však „postihnutá židovstvom“ a autorka ponúka niekol'ko odpovedí významných spoločenských vedcov, ale aj psychológov na túto traumu.

Gusztáv Kecskés mapuje posledné výstupy mad’arskej historiografie výskumu rokov 1944 - 1945, teda významný zlom v európskych, ale aj svetových dejinách. Základnou otázkou politických dejín bolo, či príchod sovietskej armády znamenal oslobodenie alebo novú okupáciu. Ciel’om článku však bolo zmapovat' predovšetkým perspektívu bežných l'udí vd’aka novým zdrojom ako denníky l'udí, listy vojnových zajatcov, cirkevných kroník Historia Domus atd'. Autor sa zaoberal individuálnymi, ale aj kolektívnymi stratégiami l'udí ako prežit' toto obdobie, ktoré znamenalo prechod z nemeckej okupácie do komunistického režimu.

V poslednom článku sa pol'ský historik Marek Mikołajczyk venuje fenoménu prekliatych vojakov. V čase druhej svetovej vojny fungovala v Pol'sku Krajinská armáda (Armia Krajowa), ktorá bola podriadená exilovej vláde v Londýne. Na konci vojny ich bolo 120 až 180 tisíc. Mnohí z nich nesúhlasili s nastupujúcim komunistickým režimom, a tak pokračovali v odboji aj po roku 1945 s ciel'om oslobodit' Pol'sko od sovietskej nadvlády. Komunistickej moci, ktorá ich predstavovala ako fašistov a banditov, sa ich činnost' podarilo úplne eliminovat' až začiatkom 60. rokov. Hoci sa historici nezhodujú na presných číslach, obete týchto bojov sa rátajú v desiatkach tisícoch. Prekliati vojaci však zanechali mimoriadne kontroverzné dedičstvo, ked’že viacerí z nich majú na svedomí množstvo civilných obetí. Kult prekliatych vojakov sa naplno rozvinul až po roku 1989, ked' sa pre mnohých stali hrdinami. Mikołajczyk však upozorňuje na kontroverznost' ich odkazu a na to, že ich nekritická heroizácia prináša nebezpečenstvo umlčania akejkol'vek zmysluplnej diskusie o povojnovom období. 
Štúdie z tohto tematického čísla Forum Historiae majú za ciel’ oboznámit’ slovenských čitatel'ov s metodologickým konceptom vystúpení z vojen, hoci sa niekedy používajú v zmysle povojnového obdobia. Z geografického pohladu sa venujú strednej Európe a Francúzsku, hoci niektoré články majú silné európske presahy. Poukazujú na zložitost' tohto procesu, či už hovoríme o politicko-diplomatickej, ale hlavne spoločenskej úrovni. Najmä svetové vojny 20. storočia často zanechali jazvy, ktoré sa aj napriek dlhému časovému obdobiu od ich ukončenia ešte nezahojili.

Cituj:

FERENČUHOVÁ, Bohumila - MARÈS, Antoine - KŠIŇAN, Michal. Vystúpenia z vojen: od napoleonských vojen po druhú svetovú vojnu. In Forum Historiae, 2018, roč. 12, č. 2, s. 1-11. ISSN 1337-6861.

$\cdots$

PhDr. Bohumila Ferenčuhová, DrSc. $\quad$ Antoine Marès

Oddelenie novších dejín

Historický ústav SAV,

P. O. Box 198,

Klemensova 19,

81499 Bratislava

histfere@savba.sk
Université de Paris 1

Panthéon-Sorbonne

Département d'histoire

1 , rue Victor Cousin

75231 Paris cedex 05

antoine.mares@wanadoo.fr
Mgr. Michal Kšiňan, PhD. Oddelenie novších dejín Historický ústav SAV, P. O. Box 198, Klemensova 19, 81499 Bratislava histksin@savba.sk 